\begin{tabular}{rr} 
çaḡdaş & Yaratıci Drama Dergisi 2018, 13(1), 69-84 \\
drama & www.yader.org \\
\hline
\end{tabular}

\title{
Ergenler İçin "Gelecek Beklentisi Farkındalık Eğitimi” Programının Etkinliğinin Sınanması
}

\author{
Ayşe Didem Konate ${ }^{1}$ \\ Derya Atalan Ergin ${ }^{2}$
}

\begin{tabular}{ll}
\hline \multicolumn{2}{l}{ Makale Bilgisi } \\
\hline DOI: $10.21612 /$ yader.2018.005 \\
\hline Makale Geçmişi & \\
Geliş tarihi & 5.5 .2017 \\
Kabul & 19.12 .2017
\end{tabular}

Anahtar Sözcükler

Gelecek beklentisi

Umutsuzluk

Yaratıcı drama

Lise ögrencileri

\begin{abstract}
Öz
Ergenlerin gelecek beklentileri oluşturmaları onların pek çok gelișim alanını destekleyici bir değişken olarak belirtilebilir. Bu çalışmada ergenlerin gelecek beklentilerini artırmak amacılla tasarlanmıs bir farkındalık programının etkililiğini değerlendirmek amaçlanmıştır. Çalı̧̧manın alt amaçlarından biri olarak ise programın umutsuzluk düzeyini düşürmedeki etkililiği değerlendirilmiştir. Programın tüm oturumları yaratıcı drama yöntem ve teknikleri kullanılarak tasarlanmıştır. Araştırmanın çalışma grubu Ankara ili Çankaya ilçesinde bulunan bir Mesleki ve Teknik Anadolu Lisesi ögrencilerinden 10. sınıfa devam eden ve katılıma gönüllü olan 32 (nkız=16, nerkek=16) ögrenciden oluşmaktadır. Çalışmada ön test son test kontrol gruplu desen kullanılmıştır. Veri toplama araçlart "Kişisel Bilgi Formu", "Geleceğe Yönelik Tutum Ölçeği” ve "Beck Umutsuzluk Ölçeği”dir. Aynı zamanda etkinlikler süresince kullanılan formlar nitel analiz ile değerlendirilmiştir. Sonuçlar deney grubunun geleceğe yönelik tutumlarının programdan sonra arttığını ve umutsuzluk düzeylerinin ise azaldiğını göstermiştir. Kontrol grubunda ise puanlar arasında anlamlı bir fark belirlenmemiştir. Nitel analiz sonuçlarına göre, ögrencilerin gelecekten en çok bir meslek sahibi olmayı bekledikleri, gelecekleri için ailelerinden ve arkadaşlarından gelen çabayı ve desteği önemsedikleri, internetin ve yaşadıkları çevrenin gelecekleri konusunda etkisinin olduğunu düşündükleri görülmüşür. Uygulanan programın ergenlerin gelecek beklentilerini ve umut düzeylerini artırmada etkili olduğu belirtilebilir.
\end{abstract}

\section{"Future Expectation” Awareness Training for Adolescents with Creative Drama Method}

\begin{tabular}{ll}
\hline Article Info \\
\hline DOI: $10.21612 /$ yader.2018.005 \\
\hline Article History \\
Received & 5.5 .2017 \\
Accepted & 19.12 .2017
\end{tabular}

Keywords

Future expectation

Hopelessness

Creative drama

High school students

\begin{abstract}
Creating future expectations can be specified as a supporting variable for many development areas of adolescents. In this study, it was aimed to evaluate the effectiveness of an awareness program designed to increase the future expectations of adolescents. One of the sub goals of this study is evaluating the effectiveness of the program in reducing the hopelessness level. All sessions of the program are designed using creative drama methods and techniques. The sample of this study consisted of 32 (ngirls $=16$ and nboys $=16$ ) voluntary high school students, who attended the 10th class of Vocational and Technical Anatolian High School in Ankara, Cankara district. In the study, pretest and posttest control group pattern was used. The data collection tools are "Personal Information Form", "Future Attitude Scale" and "Beck Hopelessness Scale". At the same time, the forms used during the activities were evaluated by qualitative analysis. The results showed that there is an increase in attitudes towards future expectations and a decrease in hopelessness levels of participants in experimental group. In control group, there are no significant differences between scores. According to the qualitative analysis results, what students most expect from the future is to have a profession; they appreciate the efforts and support from their families and friends for their future; they also think that the internet and the environment where they live in have influence on their future. It can be stated that the applied program is effective in increasing the future expectations and hope levels of adolescents.
\end{abstract}

1 MEB Fatma Yaşar Önen Mesleki ve Teknik Anadolu Lisesi, Psikolojik Danışman, E-posta: ddmteke@gmail.com

2 Yaratıcı Drama Lideri/Eğitmeni. E-posta: deryaatalan@gmail.com 


\section{Giriş}

Günümüzde teknolojideki değişimler, küreselleşme ve toplumsal dinamikler, dünyada yaşanan siyasi ve toplumsal olayların, sosyal medyanın, eğitim sisteminin, kişilerarası ilişkilerin ya da sosyo-ekonomik durumun etkisiyle ergenlerin uyum becerilerinde güçlüklere, belirsizlik hissetmelerine ve geleceğe yönelik beklentilerinde umutsuz/ karamsar olmalarına neden olmaktadır. Toplumların gelişimi ve değişiminin temel yapı taşları olarak görülen gençlerin geleceğe ilişkin beklentileri ve bu beklentilerin gerçekleşmesine yönelik umutları hem onların ruh sağlıklarını ve kendilerinden/yaşamlarından hoşnut olma düzeylerini etkileyebilmekte hem de toplumun değişimini ve bu değişimin yönünü belirleyebilmektedir (Yavuzer, Demir, Meşeci ve Sertelin, 2005). Ergenlerin gelecek beklentilerinde ve umut düzeylerinde karşılaşılabilecek kaygı, okul motivasyonlarını, akademik benlik algılarını, mesleki kariyerlerini ve sağlıklarını etkileyebilmektedir (Spielberg ve Vagg, 1995; Zeidner, 1998; Pekrun, Götz, Titz ve Perry, 2002).

Ergenlik, biyo-psikolojik bakımdan çocukluğun sonu ile toplum hayatında sorumluluk alma dönemi olan, çocukluk ve genç yetişkinlik arasında kalan gelişim dönemidir (Şahin ve Özçelik, 2016). Ergenlik dönemi, fiziksel ve duygusal süreçlerin yol açtığı, cinsel ve psikososyal olgunlaşma ile başlayan ve bireyin bağımsızlığını, kimlik duygusunu ve sosyal üretkenliğini kazandığı zaman sona eren bir dönemdir. Bu dönemde biyolojik, psikolojik ve sosyal gelişimsel değişimler gözlenmektedir (Derman, 2008).

Ergenlik, kişinin ne birçocukne de biryetişkin olduğu, henüz kendi toplumsal sorumluluklarına sahip olmadığı, ama rollerini keşfedebileceği, sınayabileceği, deneyebileceği bir ara evre olarak kabul edilir. Şu halde, toplumun, bir yol, bir kişilik, bir kimlik, bir meslek vb. seçebilmesi için gence sağladığ 1 bir mola verme zamanı, bir süre söz konusu olabilir (Onur, 1982).

Kelleci (2008) ergenliğin; gencin kimliğini oluşturduğu, gelecek için amaçlarını belirlediği, kendisi için kimin önemli ve değerli olduğu, başkaları ile ilişkilerinin nasıl olacağı, arkadaşlıklarını nasıl sürdüreceği ve yaşamında hangi yolu izleyeceğine ilişkin temel soruların yanıtlanmaya başlandığı karmaşık bir dönem olduğundan söz etmektedir.

Ergenlik dönemine ilişkin yapılmış farklı tanımlar bireyin bu dönemde tüm gelişim alanlarında değişim ve gelişim yaşadığından söz etmektedir. Kimliğin oluşturulması için soruların arttı̆̆ bu dönemde birey pek çok alanda farklı roller denemektedir. Geleceğini oluşturmak amacıyla da pek çok rol denemesi yapan ergenin gelecekle ilgili beklentilerinin çoğu yine de erişkin yaşantısının rolleri şeklindedir (Artar, 2003). "Ben kimim?" ergenlik döneminde birey için cevaplanması en önemli sorulardan biridir ve cevabı bireyin değerleri, inançları, tutumları, beklentileri gibi pek çok ögeyi içermektedir. Bireyin geleceğe yönelik amaçlar oluşturmasında kimliğin bir parçası olan güdüler, değerler ve beklentiler önemlidir (Artar 2003).

Ergenlerin gelecek beklentileri toplumdan yalıtılmış bir şekilde ortaya çıkmamaktadır. Gelecek beklentileri bireyin sosyal bağlam içerisindeki deneyimlerinden ve ilişkilerinden etkilenmektedir (Nurmi, 1991). Ergenin beklentilerinin yanında, aile ve toplumun beklentileri de ergen üzerinde bir baskı oluşturmaktadır (Uluçay, Özpolat, İşgör ve Taşkesen, 2014). Özellikle erken dönem sosyalleşme süreçleri, sosyalleşmede içinde bulunulan çevre ve etkileşime girilen diğer bireyler bu hedeflerin belirlenmesinde etkilidir. Kültürel normlar ve bu normların taşıyıcıları olan yazılı ve görsel basında istenen ve normal olan gelişimsel hedeflerin neler olabileceğini belirleyerek, 
gençlerin gelecek beklentileri için bir ölçüt oluşturmaktadır (Greene, 1990; Phinnev, Baumann ve Blanton, 2001; Kuebli, Reddy ve Gibbons, 1998; Smith ve Stones, 1999). Anne babalar ve diğer aile üyeleri, ergenin gelecek beklentilerini; model olma, doğrudan ondan beklenen görev, başarıları isteme ve bu başarılar için kriterler oluşturma yoluyla etkilemektedir (McCabe ve Barnett, 1999). Yetişkinlerin genel anlamda yaşama ilişkin değerleri gençleri etkilemekte ve gençler hedeflerini belirlerken yetişkinlerin değerlerini örnek almaktadır (Giyvin, 2001). Yaşama ilişkin değerlerin oluşmasında önemli olabilecek aileye ilişkin değişkenlerden ailenin birlikteliğgi, büyüklügüu, gelir durumu, kardeş sayısı, anne babanın eğitim düzeyi ve ailenin içinde bulunduğu çevre koşullarının gençlerin gelecek beklentilerini değiştirdiği bilinmektedir (Buyruk, 2009). Düşük sosyo ekonomik düzeyden(SED) gelen bireylerin, gelecek beklentileri yönünden daha kaderci bir düşünce yapısına sahip oldukları, bu kişilerde düşük benlik saygısı ve kötümserlik gibi duyguların öne çıktığı (Tuncer, 2011) buna karşın yüksek SED'deki bireylerde, başarıya odaklanmanın daha kolay olduğu ve bu kişilerin sosyal uyum göstermeye daha yatkın oldukları belirtilmektedir (Kağıtçıbaşı, 1973; Robert ve Bengston, 1993). Gelecek beklentisine ilişkin yapılmış çalışmalar kavramın okulu bırakma eğilimi ve disiplin cezaları gibi riskli davranışlarla (Şimşek, 2011); fiziksel ve ilişkisel zorbalıkla (Varela ve Zimmerman, 2005) negatif yönlü; yüksek benlik saygısı, baş etme yollarını kullanma (Lanz ve Rosnati, 2002) ve entelektüel yetenek(Gjesme, 1979) gibi olumlu kişilik özellikleri ile de pozitif yönlü ilişkisini göstermektedir. Yapılan tarama çalışmalarında ise ergenlerin geleceklerine yönelik iyimser oldukları görülmüştür (Seigner, 1992; Lanz ve Rosnati, 2002; Confalonieri, 2002; Malmberg 2002).

Türkiye‘de ergenler gelişim dönemine bağlı olarak bireye özgü değişimlerin yanında eğitim sisteminde ve toplumsal yaşamda da pek çok değişimle karşılaşmaktadırlar. Buna en iyi örneklerden biri öğrencilerin lisede hangi okulda eğitim göreceklerini belirleyen sınav sisteminin son 10 yılda 3 kere değişmesidir. Aynı şekilde lise müfredatları ve eğitim öğretim sisteminde, üniversiteye geçiş için öğrencilerin girdikleri sınav sistemlerinde de pek çok kereler değişim yaşanmıştır.Ayrıca Türkiye'de toplumsal alanda da hızlı değişimler yaşanmaktadır. Bu değişimlerin bir sonucu olarak 2016-2017 eğitim öğretim yılı henüz başlamadan pek çok okul kapatılmış ve bunun sonucu olarak da ergenlerin geleceklerine yönelik oluşturdukları planları hızla değiştirmeleri gerekmiştir.Tüm bu değişimler ergenleri yeniden büyük bir belirsizlik içinde bırakmaktadır. Olumsuz beklentiler ve değişken beklenti içeriklerinin bir ölçüde bireylerdeki umutsuzluğu tanımladığı da düşünülmektedir (Nurmi, 2001). Bilinmektedir ki eğitim ve öğretimde karşılaşılan güçlükler ve yoksulluk gibi etkenler ergenlerdeki umutsuzluk düzeyini arttırmaktadır (Döğer ve Kılıç, 2015).

$\mathrm{Bu}$ araştırmanın temel amacı yaratıcı drama yöntemi kullanılarak tasarlanmış bir programı liseye devam eden ergenlik dönemindeki bir grup öğrencinin gelecek beklentilerini artırmada ve umutsuzluk düzeylerini düşürmedeki etkiliğini değerlendirmektir. Türkiye'de gelecek beklentisini artırmak amacıyla hazırlanmış bir çalışmaya rastlanmamıştır. Bu nedenle araştırmacı tarafından geliştirilen 6 haftalık program katılımcı gruba uygulanmıştır. 


\section{Yöntem}

\section{Araștırma Grubu}

Çalışmanın araştırma grubu Ankara ili Çankaya İlçesi’ne bağlı bir Mesleki ve Teknik Anadolu Lisesi öğrencilerinden 10. sınıfa devam eden ve katılıma gönüllü olan toplam 32 öğrenciden oluşmaktadır. Deney grubunda 8 kız 8 erkek olmak üzere toplam 16 öğrenci, kontrol grubunda 7 kız 9 erkek toplam 16 öğrenci bulunmaktadır. Öğrenciler deney ve kontrol grubuna tesadüfi atanmıştır. Katılımcıların yaşları 15-17 arasında değişmektedir $(\overline{\mathrm{X}}=15.59$, $\mathrm{ss}=0.56)$.

\section{Veri Toplama Araçları}

Çalışmanın verileri Beck Umutsuzluk Ölçeği, Geleceğe Yönelik Tutum Ölçeği ve araştırmac1 tarafından hazırlanan kişisel bilgi formu yardımıyla toplanmıştır.

Beck Umutsuzluk Ölçeği: Beck ve arkadaşları (1974) tarafından geliştirilen ölçeğin Türkçe’ye uyarlama çalışması Durak (1993) tarafindan yapılmıştır. Ölçek 20 madde ve 3 faktörden oluşmaktadır. Faktörler gelecekle ilgili duygular, motivasyon kaybı ve gelecekle ilgili beklentiler olarak adlandırılmıştır. Ölçekteki maddeler 'Evet' veya 'Hayır' seçeneklerinden biri seçilerek yanıtlanmaktadır. Ölçeğin Cronbach Alfa iç tutarlılık katsayısı Durak (1993) tarafından .85 olarak saptanmıştır. Bu çalışmada ise ölçeğin Cronbach Alfa iç tutarlılık katsayısı .70 dir.

Geleceğe Yönelik Tutum Ölçeği: Ölçeği Güler ve İmamoğlu (2004) tarafindan geliştirilmiştir. 40 madde ve 3 faktörden oluşan ölçek öğrencilerin geleceğe yönelik tutumlarını ölçmektedir. Faktörler olumlu yönelim, kaygılı yönelim ve planlı yönelim olarak adlandırılmıştır. Beşli Likert tipi kullanılan ölçekte her bir maddenin puanlanması: '1: hiç katılmıyorum, 2: katılmıyorum, 3: ne katılıyorum, ne katılmıyorum, 4: katılıyorum ve 5: tamamen katılıyorum’ şeklinde yapılmıştır. Güler ve İmamoğlu (2004) ölçeğin Cronbach Alfa iç tutarlılık katsayısını olumlu yönelim için .80, korkulu yönelim için. 81 ve planlı yönelim için .79 olarak saptamışlardır. Bu çalışmada ise ölçeğin Cronbach Alfa iç tutarlılık katsayısı .91 olarak tespit edilmiştir.

Kişisel Bilgi Formu: Araştırmacı tarafından hazırlanmıştır. Katılımcıların cinsiyetleri ve yaşlarını içermektedir.

\section{Araştırmanın Modeli}

$\mathrm{Bu}$ çalışma yaratıcı drama yöntemi temel alınarak hazırlanmış programın öğrencilerin gelecek beklentisi ve umut düzeyleri üzerindeki etkililiğini değerlendirmeyi amaçlayan deneysel bir çalışmadır. Araştırmada ön test son test kontrol gruplu desen kullanılmıştır.

\section{Programın Uygulama Süreci}

\section{Atölyeler}

Uygulanan program altı oturumdan oluşmaktadır. Oturumlara başlamadan katılımcılara ön test uygulaması yapılmıştır. Ardından altı oturum süren program uygulanmış ve son test verileri alınmıştır. Her bir oturum 180 dakika sürmüştür. Her oturumda 10 dakikalık bir ara verilmiştir. Programın atölye başlıkları Tablo 1'de sunulmaktadır. 
Tablo 1. Atölye Başlıkları

\begin{tabular}{lll}
\hline ATÖLYE BAŞLIKLARI & ATÖLYE TARİHI & ATÖLYE SÜRESİ \\
\hline Tanışma-İletişim & $24 / 11 / 2016$ & 180 Dakika \\
\hline İlgiler & $25 / 11 / 2016$ & 180 Dakika \\
\hline İlişkisel Beklentiler & $28 / 11 / 2016$ & 180 Dakika \\
\hline Varoluşsal Beklentiler & $29 / 11 / 2016$ & 180 Dakika \\
\hline Deneysel Beklentiler & $30 / 11 / 2016$ & 180 Dakika \\
\hline Geleceğe Yönelik Kararlar/ Karar Almak & $01 / 12 / 2016$ & 180 Dakika \\
\hline
\end{tabular}

Birinci oturumda Tanışma-İletişim atölyesi uygulanmıştır. Oturumun kazanımları grup üyelerinin birbirlerinin isimlerini söylemeleri ve gelecek beklentisinin ne olduğunu bilmeleridir.

İkinci oturumda İlgiler atölyesi uygulanmıştır. Oturumun kazanımları katılımcıların ilgilerini bilmeleri, meslekler için gerekli olan ilgileri fark etmeleri ve ilgilerine ulaşmadaki engelleri fark etmeleridir.

Üçüncü oturumda İlişkisel Beklentiler atölyesi uygulanmıştır. Oturumun kazanımları sosyal çevrenin gelecek beklentisi üzerindeki etkisini fark etmeleri ve gelecekteki ilişkilerine yönelik plan yapmalarıdır.

Dördüncü oturumda Varoluşsal Beklentiler atölyesi uygulanmıştır. Oturumun kazanımları toplumsal rolünün ne olduğu konusunda farkındalık kazanması ve gelecekte toplumdaki rolüne ilişkin plan yapmasıdır.

Beşinci oturumda Deneysel Beklentiler atölyesi uygulanmıştır. Oturumun kazanımları yaşamda karşılaşılabilecek engellerin gelecek beklentisine ulaşma yollarını etkileyebileceğini fark etmesi, geleceğe yönelik belirlediği amacının ulaşılabilirliğini değerlendirmesi ve engelleri nasıl aşılabileceğini yazmasıdır.

Altıncı oturumda Geleceğe yönelik kararlar/karar almak atölyesi uygulanmıştır. Oturumun kazanımları karar alırken gelecek beklentilerini dikkate alması gerektiğini fark etmesi ve aldığı kararlar arasından uygun olanı seçmesidir.

\section{Verilerin Analizi}

Çalışmada elde edilen nicel verilerin analizi SPSS 22 paket programı kullanılarak yapılmıştır. Kişi sayısının az olması ve normal dağılımın sağlanamaması nedeniyle verilerin analizinde nonparametrik olmayan yöntemler kullanılmıştır. "Beck Umutsuzluk Ölçeği" ve "Geleceğe Yönelik Tutum Ölçeği” ilişkili ölçümlerin değerlendirilmesinde Wilcoxon işaretli sıralar analizi testi, deney ve kontrol grubu son test puanlarının karşılaştırılmasında Mann Whitney U testi kullanılmıştır.

Programın oturumları süresince uygulanan etkinliklerden elde edilen yazılı materyaller ise tema analizi ve istatistiksel içerik analizi ile değerlendirilmiştir. Tema analiziyle elde edilen kodlar daha sonra sayılara dökülerek nitel veriler nicelleştirilmiştir. Sayısallaştırma yoluyla araştırmanın güvenirliği artırılmaya, amaç yanlılığı azaltılmaya çalışılır. Bu şekilde elde edilen bulguların yorumları böylece daha adil olmaktadır. Sayısallaştırmadaki bir diğer amaç ise, ortaya çıkan tema ve kodlar arasında karşılaştırma yapmaya olanak tanımasıdır (Yıldırım ve Şimşek, 2011). 


\section{Bulgular}

Araştırmanın bulguları iki alt başlıkta verilmiştir. Bunlar; nicel analiz bulguları ve nitel analiz bulgularıdır.

\section{Nicel Analiz Bulgulart}

Çalışmanın nicel verileri 'Beck Umutsuzluk Ölçeği', 'Gelecek Beklentisi Ölçeği’ ölçme araçları ile elde edilmiştir.

Program öncesi uygulanan Gelecek Beklentisi Ölçeği deney $(\bar{X}=18.34)$ ve kontrol $(\bar{X}=$ 14.66) grubu öntest puanları ile “ Beck Umutsuzluk Ölçeği” deney $(\bar{X}=21.53)$ ve kontrol $(\bar{X}=$ 11.47) ön test puanları arasında anlamlı fark bulunmamıştır $(\mathrm{p}<.05)$. Programın uygulanmasında sonra deney ve kontrol grubundan elde edilen son test verileri Tablo 2'de sunulmaktadır.

Tablo 2. Gelecek Beklentisi Ölçeği ve Beck Umutsuzluk Ölçekleri Deney ve Kontrol Grubu Mann Whitney U Son Test Sonuçları

\begin{tabular}{|c|c|c|c|c|c|c|}
\hline & Grup & $\mathbf{n}$ & Sira Ortalama & Sira toplamı & $\mathbf{U}$ & $\mathbf{p}$ \\
\hline \multirow{2}{*}{ 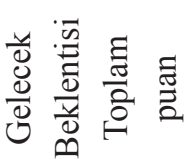 } & Deney Grubu & 16 & 21.53 & 344.50 & \multirow[t]{2}{*}{47.500} & \multirow[t]{2}{*}{0.02} \\
\hline & Kontrol Grubu & 16 & 11.47 & 183.50 & & \\
\hline \multirow{2}{*}{ 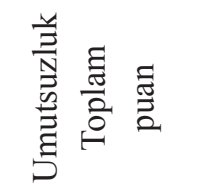 } & Deney Grubu & 16 & 11.69 & 187 & \multirow[t]{2}{*}{51.000} & \multirow[t]{2}{*}{0.003} \\
\hline & Kontrol Grubu & 16 & 21.31 & 341 & & \\
\hline
\end{tabular}

Tablo 2'ye göre deney $(\bar{X}=21.53)$ ve kontrol $(\bar{X}=11.47)$ grupları son test puanları arasında Gelecek Beklentisi toplam puanına göre anlamlı fark bulunmaktadır $(\mathrm{p}<0.05)$. Buna göre deney grubundaki öğrencilerin geleceğe yönelik tutumları kontrol grubundaki öğrencilerden yüksektir.

Beck Umutsuzluk ölçeği son test toplam puan ortalamalarına göre $(\bar{X}=11.69)$ ve kontrol $(\bar{X}=21.31)$ grupları arasında anlamlı fark bulunmaktadır $(\mathrm{p}<0.05)$. Buna göre kontrol grubundaki öğrencilerin son test puanları deney grubundaki öğrencilerden yüksektir. Gelecek beklentisi ölçeği için deney grubu Wilcoxon işaretli sıralar test sonuçları Tablo 3'de verilmiştir.

Tablo 3. Gelecek Beklentisi Ölçeği Deney Grubu Wilcoxon İşaretli Stralar Testi Sonuçları

\begin{tabular}{|c|c|c|c|c|c|c|}
\hline & $\begin{array}{l}\text { Son test - } \\
\text { Ön test }\end{array}$ & $\mathrm{N}$ & $\begin{array}{l}\text { Sira } \\
\text { Ortalamas1 }\end{array}$ & $\begin{array}{l}\text { Sira } \\
\text { Toplamı }\end{array}$ & $\mathrm{Z}$ & $\mathrm{p}$ \\
\hline \multirow{3}{*}{ 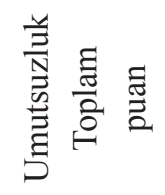 } & Negatif sira & 12 & 8.08 & 97 & -2.803 & \multirow[t]{3}{*}{0.005} \\
\hline & Pozitif sira & 2 & 4 & 8 & & \\
\hline & Eşit & 2 & & & & \\
\hline \multirow{3}{*}{ 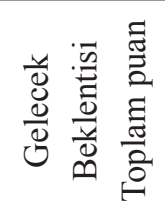 } & Negatif sira & 4 & 6.88 & 27.50 & -2.095 & 0.036 \\
\hline & Pozitif sira & 12 & 9.04 & 108.5 & & \\
\hline & Eşit & 0 & & & & \\
\hline
\end{tabular}


Tablo 3'e göre deney grubundaki öğrencilerin geleceğe yönelik tutuma ilişkin ön test ve son test puanları arasında anlamlı fark bulunmaktadır. $(\mathrm{z}=-2.095, \mathrm{p}<0.05)$. Buna göre deney grubundaki öğrencilerin Gelecek Beklentisi Ölçeği son test puanları ön test puanlarından yüksektir. Beck umutsuzluk Ölçeği için deney grubundaki öğrencilerin ön test ve son test puanları arasında anlamlı fark bulunmaktadır $(\mathrm{z}=-2.095, \mathrm{p}<0.05)$. Öğrencilerin umutsuzluk ön test puanları son test puanlarından yüksektir.

Programın uygulanmadığı kontrol grubunda ise hem Gelecek Beklentisi ön test-son test puanları $(\mathrm{z}=0, \mathrm{p}>0.05)$ hem de Beck Umutsuzluk Ölçeği ön test ve son test puanları arasında anlamlı fark bulunmamıştır $(\mathrm{z}=0, \mathrm{p}>0.05)$.

\section{Nitel Analiz Bulgulart}

İlk oturumda katılımcıların ‘Gelecekten ne beklenebilir?’ sorusunu cevaplamaları istenmiştir. Cevaplar ve ilişkili temalar Tablo 4’ te verilmiştir.

Tablo 4. Gelecek Beklentileri Temasına İlişkin Alt Tema ve Kodlar

\begin{tabular}{lll}
\hline Tema & Kodlar & f \\
\hline \multirow{2}{*}{ Başarı } & Meslek sahibi olmak & 7 \\
\cline { 2 - 3 } & Üst eğitim kurumuna devam etmek & 1 \\
\cline { 2 - 3 } & Maddi beklenti & 1 \\
\hline \multirow{2}{*}{ Ilişkisel } & Evlenmek & 1 \\
\cline { 2 - 3 } & Aşk & 2 \\
\hline \multirow{2}{*}{ Diğer } & Duyguya ilişkin & 2 \\
\cline { 2 - 3 } & Hedefe İlişkin & 2 \\
\hline
\end{tabular}

Öğrencilerin cevapları gelecek beklentisi temasında başarı, ilişkisel ve diğer alt tema başlıklarında toplanmıştır. Başarıya ilişkin beklentiler meslek sahibi olmak, üst eğitim kurumuna devam etmek ve maddi beklenti kodlarında; ilişkisel beklentiler evlenme ve aşk kodlarında; diğer teması ise duyguya ilişkin ve hedefe ilişkin kodlarında adlandırılmıştır. Öğrencilerin en fazla başarı temasındaki meslek sahibi olmak kodunda cevap verdikleri görülmüştür. Kodlara ilişkin örnek cevaplar şu şekilde sıralanabilir;

'Gelecekte güzel bir meslek sahibi olmak.' (K1, başar1-meslek sahibi olmak), , 'Evlenip mutlu olmak' (K4, İlişkisel- evlenmek), ' 'Mutluluk.' (K9, Diğer- Duyguya ilişkin).

İkinci oturumda katılımcılardan şu anda yapamadıkları ancak yapmak istedikleri bir ilgilerini ve bu ilgiye ulaşmak için engellerini yazmaları istenmiştir. Sonuçlar Tablo 5' te verilmiştir.

Tablo 5. Ilgiler ve Engeller Temasına İlişkin Tema ve Kodlar

\begin{tabular}{llllll}
\hline Tema & Kod & f & Tema & & f \\
\hline \multirow{2}{*}{ Mesleki ilgi } & İşle ilgili & 4 & \multirow{2}{*}{ Engeller } & Kendi ile ilgili & 4 \\
\cline { 2 - 3 } \cline { 2 - 3 } & Okul ile ilgili & 2 & Kendi ile ilgili & 2 \\
\hline \multirow{2}{*}{ Kültürel faaliyetler } & Spor & 5 & \multirow{2}{*}{ Engeller } & Aile ile ilgili & 4 \\
\cline { 2 - 5 } \cline { 4 - 5 } & Sanat & 2 & & Kendi ile ilgili & 3 \\
\hline
\end{tabular}


Sonuçlara bakıldığında öğrencilerin ilgilerinin mesleki ve kültürel faaliyetler temaları altında toplandığı görülmektedir. Mesleki ilgi temasına ilişkin kodlar; işle ilgili ve okul ile ilgili; kültürel faaliyetler teması ise spor ve sanat olarak iki ayrı kodda belirlenmiştir. Mesleki ilgi temasına ulaşmadaki engeller en fazla kendi ile ilgili kodunda; kültürel faaliyetlere ilişkin engeller teması ise en fazla aile ile ilgili kodunda toplanmıştır. Kodlara ilişkin örnek cevaplar şu şekilde sıralanabilir;

"Polis olmak" (K3, Mesleki ilgi-işle ilgili), "Sağlık durumu” (K3, Engeller-kendi ile ilgili), "Futbol oynamak" (K8, Kültürel Faaliyetler-Spor), "Sakatlanma ve oynayamama korkusundan dolayı ailemin göndermemesi” (K8, Engeller- Aile ile ilgili)

Üçüncü oturumda katılımcılardan 'aile', 'arkadaş', 'yaşadığı yer' ve 'internet' kavramları ile başlayan cümle tamamlama etkinliği uygulanmıştır. Verilen her bir kelime bir tema olarak değerlendirilmiştir.

Aile teması altında çaba, destek, istek ve duygu kodları; arkadaş teması altında destek, istek ve duygu kodları; yaşanan yer teması altında olumlu katk1, olumsuz etki ve önem kodları; internet teması altında katkı/etki ve önem kodları oluşturulmuştur. Kodların örnek cevapları şu şekilde siralanabilir;

'Bana destek oluyor. Tavsiyeler sunarlar.' (K1, Aile-Destek),

“'Benim okumamı istiyor.' (K3, Arkadaş-İstek),

'Sikıcı.'(K10, Yaşanan Yer- Olumsuz Etki),

'Bir o kadar iyi ama bir o kadar da kötüdür.' (K11, İnternet-Katk1/Etki)

Bir başka etkinlikte katılımcılara 30 yaşında oldukları zamanı düşünerek 17 yaşlarına mektup yazmaları istenmiştir. Temalara ilişkin bulgular Tablo 6' da verilmiştir.

Tablo 6. Geleceğe Öğ̈̈̈tler Temasına Illişkin Tema ve Kodlar

\begin{tabular}{lll}
\hline Tema & Kodlar & f \\
\hline Karar alma & Sosyal çevrenin etkisi & 9 \\
\hline Gelecek Beklentisi & Olumlu düşünce & 5 \\
\cline { 2 - 3 } & Olumsuz düşünce & 7 \\
\hline
\end{tabular}

Buna göre öğrenciler en çok karar alma süreçlerinden bu süreçte de öncelikle arkadaşları ve ailelerinin etkisinden söz etmişlerdir. Geleceğe ilişkin beklentilerde ise olumlu ve olumsuz duygular ve sorumluluk vurgusunun daha çok olduğu görülmüştür. Örnek cevaplar şu şekildedir;

'Yaptığım iyi şeyler ve kötü şeylerde arkadaşlarımın çok payı var.' (K5, Karar alma- Sosyal çevrenin etkisi),

'Hayata tekrar tutunup dönüp liseyi bitirmeye baktım. '(K2, Gelecek Beklentisi-Olumlu Düşünce)

\section{Tartışma ve Sonuç}

Yaratıcı drama yönteminin ergenler için gelecek beklentisi üzerindeki etkililiğini ele alan bu araştırma, yaratıcı drama yönteminin yaşayan, canlandıran, oynayan ergenlerin ilgilerinin, sosyal çevrelerinin, toplumsal rollerinin, yaşamda karşılaş1labilecek engellerin ve geleceğe yönelik alınan karalar konularında farkındalık geliştirmelerini hedefleyen altı yaratıcı drama temelli oturumdan oluşan programın etkililiğini göstermektedir. 
Araştırmada nicel verilerin analizi sonrasında deney grubunun geleceğe yönelik beklentilerinin yaratıcı drama temelli programdan sonra arttığı, umutsuzluk düzeylerinin ise azaldığı görülmüştür. Kontrol grubunda ise puanlar arasında herhangi bir fark belirlenmemiştir. Bu sonuca göre uygulanan yaratıcı drama temelli programın ergenlerin gelecek beklentilerini ve umut düzeylerini artırmada etkili olduğu belirtilebilir.

Çalışmanın nitel verilerinin sonuçlarına göre ise öğrencilerin gelecekten en çok bir meslek sahibi olmayı bekledikleri görülmüştür. Bu beklenti gelecek beklentisi sınıflamasında başarı teması altındadır. Yavuzer, Demir, Meşeci ve Sertelin (2005) tarafından yapılan çalışmada ise meslek, evlilik, ekonomik kazanç ve toplumsal saygınlık olarak sıralanmıştır. Toplumsal olaylar ve eğitim sistemiyle birlikte değişim gösterebileceği düşünülen gelecek beklentisinin burada dikkati çeken başlığı "meslek" olarak görülmektedir. Her iki çalışmada da ilk vurgulanan konu olarak meslek edinimi bir mesleğe sahip olmanın toplum tarafından da sürekli vurgulanan önemine işaret eder görülmektedir.

Öğrenciler gelecekleri için ailelerinden ve arkadaşlarından gelen çabayı ve desteği önemsediklerini, internetin ve yaşadıkları çevrenin gelecekleri konusunda etkisi olduğunu düşündüklerini belirtmişlerdir. Bu sonuç ergenlik döneminin de bir özelliği olarak sosyal çevrenin özellikle arkadaşlık ilişkilerinin önemini doğrulamaktadır. Cevaplar özellikle karar alma süreçlerinde sosyal çevrenin önemini göstermektedir. Öğrenciler ilgilerini belirtirken mesleki ve sanat /spor ilgilerini yaklaşık aynı oranlarda ifade etmişlerdir. Ancak çarpıcı olan bunları yapmalarına şu anda engel olan durumların mesleki ilgilerde kendileri, sanat/spor alanında ise genellikle aileden kaynaklı olduğunu belirtmeleridir. Bu durum ailelerin sanatı ve sporu çocuklarının akademik başarılarını düşürecek, zaman kaybettirici etkinlikler olarak algıladıkları gerçeğini bir kez daha göstermiştir. $\mathrm{Bu}$ çalışmadan elde edilen önemli sonuçlardan biri olarak anne baba eğitim programlarında ya da seminerlerde mutlaka sanatın ve sporun önemine değinilmesi gerektiğidir. Nitel verilerde son olarak öğrenciler gelecek beklentilerini gerçekleştirmek için en çok çabaya vurgu yapmışlardır. Bu vurgu öğrencilerin geleceklerinin kendi ellerinde olduğunu, onu yapılandırabileceklerini düşündüklerini göstermesi açısından önemlidir.

Gelecek beklentisinin oluşmasında bekleme, plan yapma, davranış düzenleme gibi pek çok bilişsel süreç ve iyimserlik, kötümserlik, umut ve umutsuzluk gibi duygular ve tutumlar etkilidir (Nurmi, 2005). Türkiye'de eğitim sistemindeki sürekli değişimlerin ve yaşanan toplumsal olayların ergenlerin geleceğe ilişkin tutumlarını olumsuz etkilediği düşünülmektedir. Bireyin hem bilişsel hem duygusal gelişimi ile ayrıca içinde yaşadığı toplumla ve sistemle de doğrudan ilişkili olan böylesi bir konuda yapılacak çalışmaların önemli olduğu düşünülmektedir. Özelikle uygulanacak programlarla kazandırılacak geleceğe yönelik olumlu beklentiler ergenlerde riskli davranışlarının azalmasından, meslek seçimine ve kimlik gelişimine kadar pek çok alanda olumlu değişimleri sağlayabilecektir.

Yaşama ilişkin değerlerin oluşmasında önemli olabilecek aileye ilişkin değişkenlerden ailenin birlikteliği, büyüklügüu, gelir durumu, kardeş sayısı, anne babanın eğitim düzeyi ve ailenin içinde bulunduğu çevre koşullarının gençlerin gelecek beklentilerini değiştirdiği bilinmektedir(Buyruk, 2009). Bu çalışmanın araştırma grubunu oluşturan öğrenciler daha çok alt-orta sosyo ekonomik düzeyden gelen ve ticaret meslek lisesinde öğrenim gören ergenlerden oluşmaktadır. Yapılan çalışmalarda da farklı lise türlerinde öğrenim görmenin gelecek beklentisini (Uluçay, Özpolat, İşgör ve Taşkesen, 2014) etkilediği gösterilmiştir. Buna göre gelecek beklentisi düzeyi okunan okul türünün puanı düştükçe azalmaktadır. Bu iki özellik de gelecek beklentisi anlamında çalışılması güç bir grup olarak görülebilir. Bu nedenle yaratıcı drama temelli programın etkililiğinin farklı sosyo ekonomik düzeyden gelen ergenlerle ve farklı okul türlerinde sınanmasının önemli olduğu düşünülmektedir. 


\section{Kaynakça}

Abramson, L. Y., Matelsky, G. L. ve Alloy, L. B. (1989). Hopelessness depression: A- theory based subtype of depression. Psychological Review, 96, 358-372.

Adıgüzel, H. Ö. (2006). Yaratıcı drama kavramı, bileşenleri ve aşamaları, Yaratıcı Drama Dergisi, Sayı 1(1).

Akfirat, F. (2006) Sosyal yeterlilik, sosyal beceri ve yaratıcı drama. Yaratıcı Drama Dergisi, 1(1).

Argarvval, A., Tripathi, K. K. ve Srivastava, M. (1983). Social roots and psychological implications of time perspective. International Journal of Psychology, 18, 367-380.

Artar, M. (2003). Depremi yaşayan ergenlerin gelecek beklentilerinin içeriği. Kriz Dergisi, 11(3), 21-27.

Aylar, E. (2012). Bir örnek olay incelemesi: Sosyo-Kültürel teori bağlamında geleceğe yönelik hedefler ve özdüzenleme. Kastamonu Ĕ̈itim Dergisi, 20(3), 767-782.

Batıgün, D. A. ve Kılıç, N. (2011). İnternet bağımlılığı ile kişilik özellikleri, sosyal destek, psikolojik belirtiler ve bazı demografik değişkenler arasındaki ilişkiler. Türk Psikoloji Dergisi, 26(67), 1-10.

Bayoğlu, A. S., Purutçuoğlu, E. (2010). Yetiştirme yurdunda kalan ergenlerin gelecek beklentileri ve sosyal destek algıları. Kriz Dergisi, 18(1), 27-39.

Buyruk, M. (2009). Ailelerin sosyo ekonomik yapısının meslek lisesi ögrencilerinin gelecek beklentisine etkileri. Yüksek Lisans Tezi, Beykent Üniversitesi, Sosyal Bilimler Enstitüsü, İstanbul.

Catalano, R. F., Berglund, M. L., Ryan, J. A., Lonczak, H. S. ve Hawkins, J. D. (2004). Positive youth development in the united states: research findings on evaluations of positive youth development programs. The annals of the American Academy of Political and Social Science, 591(1), 98-124.

Chardie, L. Baird, S. W. ve Burge, J. R. R. (2008). Absurdly ambitious? Teenagers' expectations for the future and the realities of social structure. Sociology Compass 2(3), 944-962.

Çokluk, Ö. (2000). Örğ̈̈tlerde tükenmişlik: Yönetimde çağdaş yaklaşımlar. (Edit: Cevat Elma ve Kamile Demir). Ankara: Anı Yayıncılık.

Confolonieri, E. (2002). A narratıve perspectıve on the future Transitıon to adulthood (İçinde) Adolescents' Future Onentation Theory and Research (Eds). Trempala, T., Malmberg, L. E. Frankfurt: Peter Lang.

Derman, O. (2008). Ergenlerde psikososyal gelişim. I. Ü. Cerrahpaşa Tip Fakültesi, Sürekli Tıp Eğitimi Etkinlikleri Sempozyum Dizisi, 68, 19-21.

Dilbaz, N. ve Seber, G., (1993). Umutsuzluk kavramı: Depresyon ve intiharda önemi. Kriz Dergisi, 1(3), 134138.

Dinçel, E. (2006). Ergenlik dönemi gelişimsel ödevleri ve psikolojik problemler. Yayımlanmamış yüksek lisans tezi, Ankara Üniversitesi, Sosyal Bilimler Enstitüsü.

Dodge, K. A. (1986). Social competence in children. Monographs of the society for research in child development, 2, 1-80.

Döğer, D. ve Kılıç, I. (2015). Güzel sanatlar lisesi müzik bölümü öğrencilerinin çalgı başarıları ile umutsuzluk düzeylerinin incelenmesi. E-International Journal of Educational Research, 6(3), 1-22.

Ekşi, A. (1999). Adolesanın ruhsal gelişim dönemleri ve döneme özgü sorunlar, A. Ekşi (Ed.), Ben Hasta Değilim. Ankara: Nobel Tıp Kitapevleri.

Erikson, E.H. (1968). Identity: Youth and Crisis. New York, NY: Norton.

Eryılmaz, A. (2011). Ergen öznel iyi oluşu ile olumlu gelecek beklentisi arasındaki ilişkinin incelenmesi. Düşünen Adam Psikiyatri ve Nörolojik Bilimler Dergisi, 24, 209-215.

Fischhoff, B., Parker, A. M. B., Downs, J., Palmgren, C., Dawes, R. ve Manski, C. F. (2000). Teen expectations for significant life events. Public Opinion Quarterly, 64, 189-205.

Givyin, K. B. (2001). Goal orientations of adolescents, coaches and parents: 1s there a convergence of beliefs? Journal of early adolescence, 21(2), 228-248. 
Gjesme, T. (1979). Future time orientation as a function of achievement motives, ability, delay of gratification, and sex. The Journal of Psychology, 101, 173-188.

Gönüllü, M. (2003). Lise öğrencilerinin bulunduklari liseye göre gösterdikleri toplumsal farklllıklar: Sivas ili merkez ilçe örneği. Cumhuriyet Üniversitesi Sosyoloji Tartışmaları Dergisi, 1, 28-50.

Greene, A. L. (1990). Great expectations: Constructions of the life course during adolescence. Journal of Youth And Adolescence, 19, 289-306.

Guarino, A., De Pascalis, V. ve DiChiacchio, C. (1999). Breast can cerprevention, time perspective, and trait anxiety. Unpublished Manuscript, University of Rome.

Güleri, M. (1994 ). Üniversiteli ve işçi gençliğin gelecek beklentileri ve kötümserlik- iyimserlik düzeyleri. Kriz Dergisi, 6(1), 55-65.

Heubner, E. S. (1991). Correlates of life satisfaction in children. School Psychology Quarterly, 6, 103 -111.

Hokoda, A. ve Fincham, F. D. (1995). Origins of children's helpless and mastery achievement patterns in the family. Journal of educational psychology, 87, 375-385.

Hurn, C. J. (1993). The limits and possibilities of schooling: An introduction to the sociology of education (3rd ed.). Boston: Allyn and Bacon.

Izgar, H., Gürsel, M., Kesici, Ş. ve Negiş, A. (2004). Önder davranışların problem çözme becerisine etkisi. XIII. Ulusal Ë̆itim Bilimleri Kurultayl.

İkizoğlu, M., Önal-Dölek, B. ve Gökçearslan-Çiftçi, E. (2007). Çalışan çocukların sorunları ve geleceğe ilişkin beklentileri. Toplum ve Sosyal Hizmet Dergisi, 18(2), 21-36.

İmamoğlu, O.E. ve Edwards, G. A. (2007). Geleceğe ilişkin yönelimlerde benlik tipine bağlı farklılıklar. Türk Psikoloji Dergisi 2007, 22(60), 115-132.

Kağıtçıbaşı, Ç. (1973). Gençlerin tutumları Kültürlerarası Bir Karşılaştırma. Ankara: ODTÜ.

Kazakina, E. (1999). Time perspective of older adults: relationships to attachment style, psychological well-being and psychological distress. Unpublished Doctoral Dissertation, Columbia University.

Kelleci, M. (2008). İnternet, cep telefonu, bilgisayar oyunlarının çocuk ve gençlerin ruh sağlığına etkileri. TAF Preventive Medicine Bulletin, 7 (3), 253-256.

Kuebli, J., Reddy, R. ve Gibbons, J. L. (1998). Perceptions of others in self descriptions of children and adolescence in India. The Journal of Comparative Social Science, 32, 217-240.

Lanz, M. R. (2002) Adolescents' and young adulls' construction of the future effects of family relations, self-esteem, and sense of coherence (İçinde) Adolescents> Future Onentation Theory and Research (Eds) Trempala, T., Malmberg, L. E. Frankfurt: Peter Lang.

Ling-Ling, Z. ve Wen-Xin, Z. (2008). Personal future planning in middle and late adolescence and its relation to adolescents' communication with parents and friends. Acta Psychologica Sinica, 40(5), 583-592.

McCabe, C., Kristen, D., Barnett, A., Douglas, S. (2000). First comes work, then comes marriage: future orientation among african american young adolescents. Family relations, 49, Issue 1.

McWhirter, E. H. ve McWhirter, B. T. (2008). Adolescent future expectations of work, education, family and community development of a new measure. Youth Society,40(2), 182-202.

Meece, J. (1991). The classroom context and students' motivational goals. M. Maehr, P. Pintrich (Ed), Advances in motivation and achievement, 7, 261-285. Greenwich, CT: JAI.

Mello, Z. R. (2008). Gender variation in developmental trajectories of educational and occupational expectations and attainment from adolescencet adulthood. Development Psychology, 44(4), 1069-1080.

Nurmi, J. E. (1991). How do adolescents see their future? A Review of the development of future orientation and planning. Developmental Review, 11,159-170.

Nurmi, J.E. (2001). Navigating through adolescence introduction (İçinde) Navigating through adolescence (Ed) Nurmi, J. E., New York: European Perspectives, Routledge. 
Offer, D., Schonert-Reichl, K. A. ve Boxer, A. M. (1996). Normal adolescent development: empirical research findings, (Ed M. LEWIS). Child and adolescent psychiatry, A comprehensive textbook. Baltimore: Williams and Wilkins.

Onur ,B. (1982). Ergenlik psikolojisinde kuramlar. Ankara Üniversitesi Dergisi.

Owen K. F., Karaırmak Ö. ve Owen D. W. (2013). Okul psikolojik danışmanları için el kitabı. Ankara: Anı Yayıncilik.

Önder, A. (2002). Yaşayarak ögrenme için yaratıcı drama. İstanbul: Epsilon Yayıncılık.

Özmen, D., Dündar, E. P., Çetinkaya, A., Taşkın, O. ve Özmen, E. (2008). Lise öğrencilerinde umutsuzluk ve umutsuzluk düzeyini etkileyen etkenler. Anadolu Psikiyatri Dergisi, 9, 8-15.

Pekrun, R., Götz, T., Titz, W. ve Perry, R. P. (2002). Academic emotions in studentse self-regulated learning and achievement: A program of qualitative research. Educational Psychologist, 37, 91-106.

Phinnev, J.S., Baumann, K. ve Blanton, S. (2001). Life goals and attributions for expected outcomes among adolescents from five ethnic groups. Hispanic Journal of Behavioral Sciences, 23(4), 363-377.

Raffaelli, M. ve Koller, S.H. (2005). Future expectations of Brasilian street youth. Journal of Adolescence, $28(2), 249-262$.

Salmela-Aro, K. (2001). Personal goals during the transition to young adulthood (içinde) Navigating through adolescence (Ed) Nurmi, J.E. New York: European Perspectives, Routledge.

San, İ. (1996). Yaratıcılığı geliştiren bir yöntem ve yaratıcı bireyi yetiştiren bir disiplin: Eğitsel yaratıcı drama. Yeni Türkiye Dergisi, 2(7), 148-160.

Seigner, R. (1992). Future orientation: Age related differences among adolescent females. Journal of Youth and Adolescence, 21, 421-437.

Smith, T. B. ve Stones, C. R. (1999). Identities and racial attitudes of south african and american adolescents: A cross-cultural examination. South African journal of psychology,29, 23-29.

Spielberg, C. D. ve Vagg, P. R. (1995). Test anxiety: Theory, assessment and treatment. Washington, DC: Taylor \& Francis.

Stoddard, S. A., Varela, J. J. ve Zimmerman, M. A. (2015). Future expectation, attitude toward violence, and bullying perpetration during early adolescence. Nursing Research, 64(6), 422-433.

Şahin Ş., Özçelik Ç.(2016). Ergenlik dönemi ve sosyalleşme. Cumhuriyet Hemşirelik Dergisi, 5(1):42-49

Şimşek H.(2011). Güneydoğu Anadolu bölgesindeki lise öğrencilerinin gelecek beklentileri ve gelecek beklentilerini etkileyen faktörler. Kuramsal Eğitimbilim Dergisi, 5(1), 90-109.

Tatar, M. (2005). Öğretmen beklentisi. Yüzüncü Yll Üniversitesi Elektronik Eğitim Fakültesi Dergisi, 2(2).

Tokuç, B., Turunç, Y. ve Ekuklu, G. (2009). Edirne'de ambulans çalışanlarının anksiyete, depresyon ve işe bağlı gerginlik düzeyleri. Türk Tabipleri Birliği Mesleki Sağllk ve Güvenlik Dergisi, 42, 39-44.

Tuncer M. (2011). Yükseköğretim gençliğinin gelecek beklentileri üzerine bir araştırma. International Periodical For The Languages, Literature and History of Turkish or Turkic, 6(2), 935-948.

Turcios-Cotto, V. ve Milan, S., (2013). Racial/ ethnic differences in the educational expectations of adolescents: does pursuing higher education mean some thing different to latino students comparedto white and black students?, Journal of Youth \& Adolescence, 42 (9).

Uluçay, T., Özpolat, A. R., İşgör, İ. Y. ve Taşkesen, O. (2014). Lise öğrencilerinin gelecek beklentileri üzerine bir araştırma. NWSA-Education Sciences, 9(2), 234-247.

Üstündağ, T. (2002). Yaratıcllı̆̆a yolculuk. Ankara: Pegem Akademik Yayınc1lık.

Wikipedia (2016) Https://tr.wikipedia.org/wiki/Ludwig van Beethoven. E. T. 08.10.2016. internet sitesinden 14.03.2016 tarhinde edinilmiştir.

Yavuzer H., Demir İ., Meşeci F., Sertelin Ç.(2005). Günümüz gençliğinin gelecek beklentileri. Hasan Ali Yücel Eğitim Fakültesi Dergisi, 2, 93-103.

Yıldırım, A. ve Şimşek, H. (2011). Sosyal bilimlerde nitel araştırma yöntemleri. Ankara: Seçkin Yayıncılık. 


\section{Ek 1: Örnek Ders Planı}

\section{Dördüncü Oturum}

Tarih : 29/11/2016

Yer : Fatma Yaşar Önen Mesleki ve Teknik Anadolu Lisesi Çok Amaçlı Salon

Süre : 180 dakika

Konu : Varoluşsal Beklentiler

Grup : Ankara İli, Çankaya İlçesi, Fatma Yaşar Önen Mesleki ve Teknik Anadolu Lisesinde öğrenim gören $8 \mathrm{~K}, 8 \mathrm{E} 16$ öğrenci.

Yöntem : Yaratıc1 Drama

Teknik : Rol oynama, doğaçlama, dedikodu halkası, bilinç koridoru, donuk imge.

Araç- Gereçler: 16 tane Kağıt, 16 tane kalem, Marc Anthony “Vivir Mi Vida” şarkısı, resimler.

\section{Kazanımlar :}

- Toplumsal rolünün ne olduğu konusunda farkındalık kazanır.

- Gelecekte toplumdaki rolüne ilişkin plan yapar.

\section{Süreç}

\section{A-Hazırlık/ Isınma}

\section{Etkinlik 1:}

\section{Kopekbalığı Oyunu}

Katılımcılardan mekanda serbestçe dolaşmaları istenir. Lider bir süre sonra herkesin durmasını ister. Lider "Biraz sonra gözlerinizi kapatmanızı isteyeceğim. O sırada omzuna dokunduğum kişi köpekbalığı olacak. Köpekbalığının görevi diğer balıklara farkettirmeden göz kırparak olabildiğince çok balık öldürmek. Balıklar da köpekbalığının kim olduğunu bulmaya çalışacak. Ölen balık içinden 5'e kadar sayıp çığlık atarak oyunun dışına çıkacak. Her balığın üç tahmin hakkı var. Eğer 3 tahmininiz de de köpekbalığını bulamazsanız oyundan çıkarsınız. Tüm balıklar ve köpekbalığı mekanda dolaşacak. Şimdi gözlerinizi kapatın” yönergesini verir ve bir kişinin omzuna dokunarak oyunu başlatır.

\section{Etkinlik 2:}

Katılımcılardan "Vivir Mi Vida" şarkısı eşliğinde önce kendi ritimlerinde yürümeleri daha sonra da verilen yönergeler doğrultusunda yürümeleri istenir:

- Öğrenci gibi,

- Anne gibi,

- Çocuk gibi,

- Müdür gibi,

- Manken gibi,

- Futbol oynayan biri gibi 


\section{Ara Değerlendirme}

Lider yapılan iki etkinlikte çeşitli roller olduğunu vurgular. Toplumda da çeşitli roller olduğu ve her insanın da farklı roller olabileceği tartışılır. Lider katılımcılara "Şu anda toplumdaki rolleriniz neler?" sorusunu sorar ve cevaplar paylaşılır.

$$
\begin{aligned}
& K-1 \text { : 'Öğrenci .' } \\
& \text { K-2: 'Abla.' } \\
& \text { K-3: 'Abi.' }
\end{aligned}
$$

\section{Etkinlik 3:}

Lider katılımcılardan bir mekan düşünmelerini ve bu mekan içinde bir rol üstlenmelerini belirtir, elini çırptığında o mekan içindeki toplumsal rolüne uygun formu alarak donmalarını ve ikinci kez elini çırptığında o toplumsal rolüne ilişkin plan düşünmelerini belirtir. Daha sonra liderin dokunduğu kişi toplumsal rolünün ne olduğunu ve geleceğe dair düşündüğü planını söyler.

\section{B-Canlandırma}

\section{Etkinlik 4:}

Lider tahtaya (Ek-4) resimleri asar ve her resmin altına bir kağıt yapıştırır. Lider katılımcılardan her bir resimdeki kişinin toplumsal rollerinin neler olabileceğini düşünmelerini ve altındaki kağıda yazmalarını ister. Daha sonra lider katılımcıları dört gruba ayırır ve her grubun bir resim seçip resimdeki kişinin bir gününü toplumsal rollerini de anlatacak şekilde canlandırmalarını ister.

\section{Etkinlik 5:}

Lider 2008 yılında Öğrenci Seçme Sınavından yüksek puan alan İrfan Töreci‘nin gazete haberini katılımcılara okur.

Hakkarili tek kollu çoban Hacettepe Tıp'1 kazand1.

Hakkari'nin Yüksekova İlçesi'nde yaşayan ve çobanlık yapan 19 yaşındaki İrfan Töreci, ÖSS'de yüksek puan alarak Hacettepe Üniversitesi Tıp Fakültesi İngilizce Tıp bölümüne yerleşti. Yüksekova İlçesi'nde 12 kişilik ailenin çocuğu olan İrfan Töreci, 5 yaşındayken elektrik çarpması sonucu sağ kolunu kaybetti. Ancak hayata sımsıkı sarılan Töreci bir yandan eğitimini sürdürürken, boş zamanlarında da çobanlık yaptı. Töreci okuma azmini hiç yitirmeyerek doktor olmayı hedefledi. Bedensel engeline ve yoksulluğa rağmen yılmayan İrfan Töreci, Hacettepe Üniversitesi Tıp Fakültesi İngilizce Tıp bölümüne girmeyi başardı.Toprak bir evde ailesiyle birlikte maddi sıkıntı içinde yasayan İrfan Töreci, "Çocuk yaşımda doktorsuzluk yüzünden kolumu kaybettim. Ancak bu durum bana engel olmadı. Beni daha çok kamçıladı. Çok çalıştım ve başardım. Doktor olacağım için çok mutluyum" diye konuştu.

Lider katılımcıları dört gruba ayırır. Birinci grubun İrfan Töreci 'nin ailesi, ikinci grubun arkadaşları, üçüncü grubun öğretmenleri ve dördüncü grubun komşuları olduğunu söyler. Lider “İrfan Töreci 'nin Öğrenci Seçme Sınavından yüksek puan alıp tıp fakültesini kazandığını şimdi öğrendiniz. Aranızda bu haber üzerine konuşuyorsunuz." yönergesini verir. Her grup kendi içinde çember oluşturur ve olayla ilgili konuşurlar. 
Canlandırmalar bittikten sonra lider İrfan Töreci 'nin arkadaşlarının, ailesinin, komşularının ve öğretmenlerinin neler konuştuğunu tüm gruba anlatmalarını ister ve sonra tüm grupla "arkadaş, komşu, öğretmen ve aile” toplumsal rollerinin içeriği tartış1lır.

\section{Etkinlik 6:}

Lider katılımcılara Hacettepe Üniversitesi’nin İrfan Töreci ile ilgili yaptığı açıklamayı okur. Cerrah olamaz ama...

Hacettepe Üniversitesi Rektör Yardımcısı Prof. Dr. Sevil Gürgan, Hakkari’nin Yüksekova ilçesinde çobanlık yapan ve Hacettepe Üniversitesi Tıp Fakültesi İngilizce bölümünü kazanan İrfan Töreci'nin sağ kolu olmadığı için zorlanacağını belirterek, 'Özellikle cerrahi branşlarda uzmanlaşması imkansız. Ama uygun disiplinlere yönlendirildiğinde mesleğini icra edebilir” dedi.

Gruptan bir gönüllü İrfan Töreci’nin rolüne girer. Lider diğer katılımcıları 1-2 diye sayarak iki gruba ayırır. Gruplardan karş1lıklı durarak bir koridor oluşturmalarını ister. Memleketine dönüp oradaki insanlara yardım etmek mi, yurt dışına gidip eğitimini sürdürerek dünya çapında tanınan bir bilim insanı olmak mı? Soldaki grup memleketine dönüp oradaki insanlara yardım etmesinin sağdaki grup ise yurt dışına gidip eğitimini sürdürerek dünya çapında tanınan bir bilim insanı olmasının kazandıracaklarına ilişkin fikirler söylerler. Ana karakter koridor içerisinde kimin önüne gelirse, koridordaki kişiler ana karakterin vermesi gereken karara ilişkin görüşlerini belirtirler. Koridorun sonunda İrfan Töreci rolündeki kişinin kararını söylemesi istenir.

\section{C-Değerlendirme}

\section{Etkinlik 7:}

Lider katılımcılara kahramanlarının toplumsal rollerinin neler olduğunu ve gelecekteki toplumsal rollerine ilişkin planlarını yazmalarını ister.

\section{Etkinlik 8:}

Lider tüm katılımcıların birlikte bir heykel oluşturmalarını ister. Lider "ilk kişi bugüne ilişkin düşüncesini anlatan bir form alacak. Diğer kişi onu tamamladığını ve kendi düşüncesini de içeren başka bir form alacak. Böylece tüm grup üyeleri heykelin bir parçasını oluşturmuş olacak” yönergesini verir. Katılımcıların tümü bir araya gelerek bir heykel oluştururlar. Lider katılımcıların yanlarına gelip onlara dokunduğu zaman heykellerden bir cümle ile günü özetlemeleri istenir. 
Ayşe Didem Konate \& Derya Atalan Ergin - Yaratıcı Drama Dergisi 2018, 13(1), 69-87 